\title{
The Dynamic Relationship of Domestic Credit and Stock Market Liquidity on the Economic Growth of the Philippines
}

\author{
Abraham C. CAMBA, Jr. ${ }^{1}$, Aileen L. CAMBA ${ }^{2}$ \\ Received: September 30, 2019 Revised: November 01, 2019 Accepted: November 15, 2019
}

\begin{abstract}
The paper examines the dynamic relationship of domestic credit and stock market liquidity on the economic growth of the Philippines from 1995 to 2018 applying the autoregressive distributed lag (ARDL) bounds testing approach to cointegration, together with Granger causality test based on vector error correction model (VECM). The ARDL model indicated a long-run relationship of domestic credit and stock market liquidity on GDP growth. When the GDP per capita is the dependent variable there is weak cointegration. Also, the Johansen cointegration test confirmed the existence of long-run relationship of domestic credit and stock market liquidity both on GDP growth and GDP per capita. The VECM concludes a long-run causality running from domestic credit and stock market liquidity to GDP growth. At levels, domestic credit has significant short-run causal relationship with GDP growth. As for stock market liquidity at first lag, has significant short-run causal relationship with GDP growth. With regards to VECM for GDP per capita, domestic credit and stock market liquidity indicates no significant dynamic adjustment to a new equilibrium if a disturbance occurs in the whole system. At levels, the results indicated the presence of short-run causality from stock market liquidity and GDP per capita. The CUSUMSQ plot complements the findings of the CUSUM plot that the estimated models for GDP growth and GDP per capita were stable.
\end{abstract}

Keywords : Autoregressive Distributive Lag Bounds Testing, Causality, Domestic Credit, Economic Growth, Stocks Liquidity, Vector Error Correction Model

JEL Classification Code : G30, G32, C10, C13, C22

\section{Introduction}

The banking sector is an integral part of the Philippine economy because it plays a key role in providing credit to achieve long-term economic growth. If credits from banks are used to purchase productive resources, it helps in

\footnotetext{
1 First Author and Corresponding Author, Assistant Professor II, Department of Economics, College of Social Sciences and Development, Polytechnic University of the Philippines, Philippines. [Postal Address: 512 Unit Villa Alicia III, P. Tuazon Avenue, Bgry. Kaunlaran, Quezon City, Metro Manila, 1111, Philippines] Email: accamba@pup.edu.ph

2 Associate Professor IV, Department of Economics, College of Social Sciences and Development, Polytechnic University of the Philippines, Sta. Mesa, Manila, Philippines. Email: alcamba@pup.edu.ph

(c) Copyright: Korean Distribution Science Association (KODISA)

This is an Open Access article distributed under the terms of the Creative Commons Attribution Non-Commercial License (http://Creativecommons.org/licenses/by-nc/4.0/) which permits unrestricted noncommercial use, distribution, and reproduction in any medium, provided the original work is properly cited.
}

economic growth and adds to income. In fact, Beck, Levine and Loayza (2000) confirmed that financial intermediaries (i.e., banks) positively impact total factor productivity which feeds through to overall GDP growth.

Likewise, the stock market is an important pillar in promoting economic growth because it plays a crucial role in the growth of the industry and commerce which ultimately affects the aggregate economy (Ho \& Odhiambo, 2015). Paudel (2005) confirmed that stock markets, on account of liquidity, helps firms to quickly raise much needed funds for investment and growth. Increases in stock market liquidity are important as they restore the confidence of investors in the value of information associated with trading (Rousseau \& Wachtel, 2000). As investors are encouraged by high market liquidity to invest in equities, increasing the flow of venture capital, such moves would efficiently allocate resources and hence enhance economic growth in the long-run. According to Arestis, Demetriades and Luintel (2001), stock markets make financial assets less 
risky, and gives companies easy access to capital through equity issues. This leads to improvement in capital allocation and serves as a channel for economic growth.

Given the key roles provided by banks and stock markets, their contribution in the economic development of emerging market economies, such as the Philippines, cannot be underestimated. Thus, this study fills the research gap about the dynamic relationship of domestic credit from banks and stock market liquidity on the economic growth of the Philippines covering the period 1995 to 2018.

\section{Literature Review}

\subsection{Financial Development-Economic Growth Nexus: Theoretical Background}

The notion that financial market development (i.e., banking sector development and stock market development) may be related with economic growth is not new (Rousseau \& Wachtel, 2000; Beck \& Levine, 2003). The most efficient allocation of capital is achieved with development of financial markets and letting the market allocate the capital. But if the financial market is composed of banks only, the market will fail to achieve efficient allocation of capital because of the shortcoming of debt finance in the presence of asymmetric information. Thus, the development of stock markets is necessary to achieve full efficiency of capital allocation in an environment with highly liberalize financial system. While banks finance only well-established, safe borrowers, stock markets can finance risky, productive and innovative investment projects. The primary benefit of a stock market is that it constitutes a liquid trading and price determining mechanism for a diverse range of financial instruments. This allows risk spreading by capital raisers and investors and matching of the maturity preferences of capital raisers (generally long-term) and investors (shortterm). This in turn stimulates investment and lowers the cost of capital, contributing in the long term to economic growth (Caporale, Howells, \& Soliman, 2004). Theoretically, financial market development (i.e., banking sector (w) and stock market development $(\mathrm{x})$ ) causes and predict the future growth of the economy (y), thus, $y=f(x, w)$.

\subsection{Domestic Credit-Economic Growth Nexus: Selected Evidence from Asia}

Few selected studies which attempted to examine the domestic credit-economic growth link in the context of Asian countries using panel data are cited here. Krishnankutty (2011) attempted to see the relationship between banks credit and economic growth using the panel data for North East India from 1999 to 2007. The study found that banks credit to different segments of North East India does not have much impact on economic growth. The main reason for this is mainly because of default in payment and lack of monitoring by the authorities. Bayar (2014) investigated the role of development of financial sector on economic growth in 7 Emerging Asian markets (China, India, Indonesia, Korea, Malaysia, Philippines, Thailand) during the period 1992-2011 using panel regression. He found that financial sector development measured in terms of private credit by deposit money banks and other financial institutions were statistically significant and had positive effect on economic growth. In particular, a 1 percent increase in private credit by deposit money banks and other financial institutions caused a 4.82 percent increase in the economic growth in emerging 7 Asian countries during the 1990s and 2000s.

The paper of Rana and Barua (2015) examined the relationship between financial development and economic growth using panel data for 5 emerging South Asian countries - Bangladesh, India, Nepal, Pakistan and Sri Lanka. Interestingly, they found that domestic credit has no considerable influence on fostering economic growth which is generally unexpected. The paper places 3 arguments to explain these results: 1) the development of South Asian economies substantially depends on how much and in what ways government spend its money and still it has greater influence over private sector investment to foster economic growth, 2) to finance deficits and development budgets, governments continue to finance huge sum of fund through alternative market interventions such as government savings securities, post-office saving scheme etc. that also pulls the public savings into the government pocket, and 3) the lack of effective state machinery and a well efficient financial system would certainly not allow the economy to function well. Patra and Dastidar (2018) examined the empirical relationship between domestic credit and economic growth for five South Asian (Bangladesh, India, Nepal, Pakistan, and Sri Lanka) countries over the time period 1990-2015, using both panel model approach and time series analysis. They observed the positive but insignificant impact on economic growth of domestic credit provided by the banks to the private sector and domestic credit provided by the financial sector as a whole for South Asian countries. The results reveal that the impediments for the private firms for accessing financial capital are still present and that the government largely drives the investments in these economies. Similarly, this is indicative of the fact that there is still a significant room for development for the financial sectors in these economies.

Some focused their study on the causal link from the context of individual country specific data. Vaithilingam, Guru and Shanmugam (2003) investigated the causal relationship between bank lending and economic growth in Malaysia. The findings indicate direct causality running from bank lending to economic growth and an indirect impact from economic growth to bank lending in Malaysia. Thus, it can be logically assumed that a rapidly growing banking sector can play a key role in improving general economic performance. Caporale, Howells and Soliman 
(2004) uses VAR procedures to examine the causal linkage between stock market development, bank development and economic growth. They found that economic growth has a causal influence on domestic credit in Korea, Malaysia and Philippines. Rudra, Nishigaki and Hall (2017) examined the long-run relationship between financial depth, inflation and economic growth in India and Pakistan using autoregressive distributive lag bounds testing procedure and vector error correction modelling approach. The ARDL cointegration results showed that financial depth measured in terms of domestic credit to private sector and domestic credit provided by banking sector were cointegrated with economic growth. The estimated results of VECM indicate unidirectional causality from domestic credit to private sector to economic growth in the case of India. As for Pakistan, the results also indicate unidirectional causality from domestic credit provided by banking sector to economic growth.

Khanal (2007) made a comparative study on banking and insurance services liberalization and development in Bangladesh, Nepal and Malaysia on which he pointed out the continued limited access by the poor and small business to credit. The results from the econometric analysis suggest that there is a positive link between economic growth and financial deepening. Bhusal (2012) analyzed the impact of policy reforms on financial development and economic growth in Nepal seemed ineffective due to the inadequate expansion of commercial banks and their branches in the rural non-monetized sector, non-performing loans that discouraged credit allocation. Kharel and Pokhrel (2012) analyzed the situation of financial structure of Nepal and they concluded that the banking sector plays a pivotal role in promoting the economic growth or more growth enhancing relative to capital market in Nepal. Acharya (2015) examined the relationship between GDP, domestic credit and exports of Nepal employing vector autoregressive model and variance decomposition. Results showed that the influence of the shock or innovation of domestic credit to economic growth is almost doubled in the long-run as compared to that of short-run. In particular, the short-run shock to domestic credit can cause 2.06 percent fluctuation in GDP. In the long-run the impulse or innovation or shock to domestic credit account 4.65 percent fluctuation in GDP which is almost doubled from the short-run innovation.

\subsection{Stock Market Liquidity-Economic Growth Nexus: Selected Evidence from Asia}

Caporale, Howells and Soliman (2004) found a robust causal relationship between stock market development measured by share value traded ratio (i.e., market liquidity) and economic growth. Thus, causality tests indicate that the share value traded ratio has a causal effect on economic growth in Korea, Malaysia, and Philippines. Nazir, Nawaz and Gilani (2010) investigated the relationship between the stock market development and economic growth in Pakistan for the period of 1986 to 2008. For this purpose, they used two measures of stock market development, that is, size and liquidity. Both variables affected the economic growth positively and significantly.

Bhattacharya, Bhattacharya and Basu (2019) delves into the relationship between stock market movements and its endogenous liquidity parameters using ARDL bounds testing approach in the Indian context. Accordingly, all the liquidity measures which are significant in the long-run analysis are also significant in short-run. The short-run estimates have the same signs as that of long-run estimates except for turnover rate. The turnover rate negatively impacts the stock market in the short run but positively in the long run. The high-cost structure is inherent in the Indian stock market, high turnover indicates higher costs which negatively impacts the stock market in short run but in the longer period, the cost gets absorbed, and the nature of association reverses. They emphasized that low market liquidity may drive up the cost of equity, possibly depressing business investment and economic activity.

\section{Research Methods}

\subsection{Data and Model Specification}

The dependent variable economic growth is measured in terms of GDP growth (GDPGRW) and GDP per capita (GDPCAP). The independent variables of this study consists of domestic credit measured in terms of domestic credit to private sector by banks (CREDIT) and stock market liquidity is measured in terms of turnover ratio of domestic shares (STOCKS). The annual time series secondary data from 1995 to 2018 for the Philippines were obtained from the World Development Indicators by the World Bank.

\subsubsection{Cointegration Based on Autoregressive Distributed Lag (ARDL) Model \\ The Autoregressive Distributed Lag (ARDL) bounds} testing approach to cointegration is preferred because it provides consistent results for small observations (Pesaran \& Shin, 1999). The ARDL bounds testing approach was used to examine the long-run cointegration relationship of domestic credit and stock market liquidity on economic growth. The ARDL models can be expressed as follows: 


\section{MODEL 1. GDPGRW, CREDIT, STOCKS}

$$
\begin{aligned}
& \triangle G D P G R W_{t}=\mu_{11 G D P G R W}+\sum_{i=1}^{p} \gamma_{11 G D P G R W_{i}} \Delta G D P G R W_{t-i}+\sum_{j=1}^{q} \alpha_{11 G D P G R W_{j}} \Delta C R E D I T_{t-j} \\
& +\sum_{k=1}^{r} \beta_{11 G D P G R W_{k}} \Delta \text { STOCKS }_{t-k}+\delta_{11 G D P G R W} G D P G R W_{t-1}+\omega_{11 G D P G R W} C_{R E D I T} T_{t-1}+ \\
& \rho_{11 G D P G R W} \operatorname{CSTOCKS}_{t-1}+\varphi_{11 t}
\end{aligned}
$$

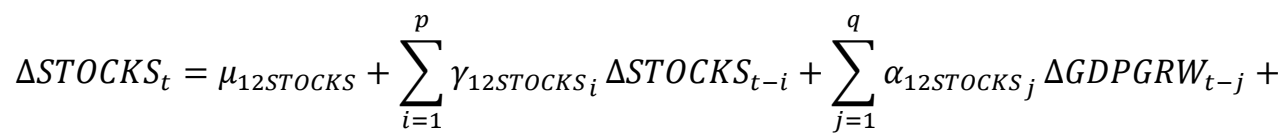

$$
\begin{aligned}
& \sum_{k=1}^{r} \beta_{12 \text { STOCKS }_{k}} \Delta \text { CREDIT }_{t-k}+\delta_{12 \text { STOCKS STOCKS }}+\omega_{t-1}+\omega_{12 \text { STOCKS }} \text { GDPGRW }_{t-1}+ \\
& \rho_{12 \text { STOCKS }} \text { CREDIT }_{t-1}+\vartheta_{11 t} \\
& \Delta \operatorname{CREDIT}_{t}=\mu_{13 C R E D I T}+\sum_{i=1}^{p} \gamma_{13 C R E D I T} \Delta \operatorname{CREDIT}_{t-i}+\sum_{j=1}^{q} \alpha_{13 C R E D I T} \Delta S T O C K S_{t-j}+ \\
& \sum_{k=1}^{r} \beta_{13 \text { CREDIT }_{k}} \Delta G D P G R W_{t-k}+\delta_{13 \text { CREDIT }} \text { CREDIT }_{t-1}+\omega_{13 \text { CREDIT }} \text { STOCKS }_{t-1}+ \\
& \rho_{13 C R E D I T} G D P G R W_{t-1}+\Omega_{11 t}
\end{aligned}
$$

\section{MODEL 2. GDPCAP, CREDIT, STOCKS}

$$
\begin{gathered}
\triangle G D P C A P_{t}=\mu_{11 G D P C A P}+\sum_{i=1}^{p} \gamma_{11 G D P C A P_{i}} \Delta G D P C A P_{t-i}+\sum_{j=1}^{q} \alpha_{11 G D P C A P} \Delta C R E D I T_{t-j}+ \\
\sum_{k=1}^{r} \beta_{11 G D P C A P_{k}} \Delta S T O C K S_{t-k}+\delta_{11 G D P C A P G D P C A P_{t-1}}+\omega_{11 G D P C A P} C_{1 R E D I T} T_{t-1}+ \\
\rho_{11 G D P C A P} C S T O C K S_{t-1}+\varphi_{11 t}
\end{gathered}
$$

$\Delta$ STOCKS $_{t}=\mu_{12 \text { STOCKS }}+\sum_{i=1}^{p} \gamma_{12 \text { STOCKS }}$ DSTOCKS $S_{t-i}+\sum_{j=1}^{q} \alpha_{12 \text { STOCKS }_{j}} \Delta$ GDPCAP $_{t-j}+$

$$
\begin{aligned}
& \sum_{k=1}^{r} \beta_{12 \text { STоскS }_{k}} \Delta \text { CREDIT }_{t-k}+\delta_{12 \text { SтоскS }} \text { STOCKS }_{t-1}+\omega_{12 \text { SтоскS }} \text { SDPCAP }_{t-1}+ \\
& \rho_{12 \text { STOCKS }} \text { CREDIT }_{t-1}+\vartheta_{11 t}
\end{aligned}
$$

$\Delta$ CREDIT $_{t}=\mu_{13 C R E D I T}+\sum_{i=1}^{p} \gamma_{13 C R E D I T} \Delta C R E D I T_{t-i}+\sum_{j=1}^{q} \alpha_{13 C R E D I T} \Delta S T O C K S_{t-j}+$

$$
\begin{aligned}
& \sum_{k=1}^{r} \beta_{13 \text { CREDIT }} \Delta \text { GDPCAP } P_{t-k}+\delta_{13 C R E D I T} \text { CREDIT }_{t-1}+\omega_{13 C R E D I T} \text { STOCKS }_{t-1}+ \\
& \rho_{13 C R E D I T} G D P C A P_{t-1}+\Omega_{11 t}
\end{aligned}
$$

where:

$\Delta=$ represent change

$\mu=$ the drift component

$\varphi, \quad \vartheta$ and $\Omega=$ are white noise error terms

$\gamma, \quad$ and $\quad=$ are short-run coefficients

$\delta, \omega$ and $\rho=$ are the corresponding long-run multiplier of the underlying ARDL model

The null hypotheses are tested using the generalized Fstatistics. The test involves asymptotic critical value bounds, depending on whether the variables are $\mathrm{I}(0)$ and/or I(1). The critical values for the $\mathrm{I}(1)$ series are referred to as upper 
bound critical values; the critical values for the $\mathrm{I}(0)$ series are referred to as lower bound critical values (Pesaran, Shin, \& Smith, 2001; Narayan \& Smyth, 2005). If the computed F-statistics are above the upper bound, the null hypothesis of no cointegration needs to be rejected, indicating evidence of a long-run equilibrium relationship between the variables, regardless of the order of integration of the variables. If the test statistic falls below the lower bound, we cannot reject the null hypothesis of cointegration, indicating the absence of a long-run equilibrium relationship. To determine the order of integration of the series, $\mathrm{I}(0)$ or $\mathrm{I}(1)$, this study employed the Augmented Dickey-Fuller unit root test (Dickey \& Fuller, 1981) and the Phillips-Perron test (Phillips \& Perron, 1988).

We also verified the long-run relationship through the cointegration test of Johansen (1988). Johansen cointegration test utilizes trace statistic and max-eigenvalue statistic in order to test whether the series is cointegrated with another series.

\subsubsection{Granger Causality Based on Vector Error Correction Model (VECM)}

The study uses Granger causality test based on vector error correction model (VECM) to establish the dynamic causal relations between economic growth, domestic credit and stock market liquidity. However, the precondition to this approach is to determine the existence of cointegration among the above-mentioned variables. After the long-run equilibrium relationship have been established, the next step is to examine the short- and long-run Granger causality between economic growth, domestic credit and stock market liquidity using the vector error correction model approach:

\section{MODEL 1. GDPGRW, CREDIT, STOCKS}

$$
\begin{aligned}
& \triangle G D P G R W_{t}=A_{11 G D P G R W}+\sum_{j=1}^{p} B_{11 G D P G R W} \Delta G D P G R W_{t-j}+\sum_{j=1}^{q} C_{11 G D P G R W} \Delta C R E D I T_{t-j} \\
& +\sum_{j=1}^{r} D_{11 G D P G R W} \Delta S T O C K S_{t-j}+v_{1 G D P G R W} E C M_{t-1}+\varepsilon_{1 t} \\
& \triangle C R E D I T_{t}=A_{21 C R E D I T}+\sum_{j=1}^{p} B_{21 C R E D I T} \Delta C R E D I T_{t-j}+\sum_{j=1}^{q} C_{21 C R E D I T} \Delta G D P G R W_{t-j} \\
& +\sum_{j=1}^{r} D_{21 C R E D I T} \Delta S T O C K S_{t-j}+v_{2 C R E D I T} E_{C M} M_{t-1}+\varepsilon_{2 t} \\
& \triangle S T O C K S_{t}=A_{31 \text { STOCKS }}+\sum_{j=1}^{p} B_{31 \text { STOCKS }} \Delta \text { STOCKS }_{t-j}+\sum_{j=1}^{q} C_{31 \text { STOCKS }} \Delta \text { CREDIT }_{t-j} \\
& +\sum_{j=1}^{r} D_{31 \text { STоскS }} \Delta G D P G R W_{t-j}+v_{3 \text { STOскS }} E_{C M} M_{t-1}+\varepsilon_{3 t}
\end{aligned}
$$

\section{MODEL 2. GDPCAP, CREDIT, STOCKS}

$$
\begin{aligned}
& \triangle G D P C A P_{t}=A_{11 G D P C A P}+\sum_{j=1}^{p} B_{11 G D P C A P} \triangle G D P C A P_{t-j}+\sum_{j=1}^{q} C_{11 G D P C A P} \Delta C R E D I T_{t-j} \\
& +\sum_{j=1}^{r} D_{11 G D P C A P} \triangle S T O C K S_{t-j}+v_{1 G D P C A P} E C M_{t-1}+\varepsilon_{1 t} \\
& \triangle C R E D I T_{t}=A_{21 C R E D I T}+\sum_{j=1}^{p} B_{21 C R E D I T} \Delta C R E D I T_{t-j}+\sum_{j=1}^{q} C_{21 C R E D I T} \Delta G D P C A P_{t-j} \\
& +\sum_{j=1}^{r} D_{21 C R E D I T} \Delta S T O C K S_{t-j}+v_{2 C R E D I T} \text { ECM }_{t-1}+\varepsilon_{2 t} \\
& \triangle \text { STOCKS }_{t}=A_{31 \text { STOCKS }}+\sum_{j=1}^{p} B_{31 \text { STOCKS }} \Delta \text { STOCKS }_{t-j}+\sum_{j=1}^{q} C_{31 \text { STOCKS }} \Delta C R E D I T_{t-j} \\
& +\sum_{j=1}^{r} D_{31 \text { STOCKS }} \Delta G D P C A P_{t-j}+v_{3 \text { STоскS }} E_{C M} M_{t-1}+\varepsilon_{3 t}
\end{aligned}
$$

where:

$\mathrm{A}_{\mathrm{ij}}, \mathrm{B}_{\mathrm{ij}}, \mathrm{C}_{\mathrm{ij}}$ and $\mathrm{D}_{\mathrm{ij}}=$ are short-run coefficients

$\mathrm{v}_{1}, \mathrm{v}_{2}$, and $\mathrm{v}_{3}=$ are long-run coefficients
$\mathrm{ECM}_{\mathrm{t}-1}=$ represents the lagged error term

It can be noted that the estimations of both ARDL and VECM are sensitive to lag length. We used the Akaike 
information criterion to choose the optimum lag length (Burnham \& Anderson, 2004). Moreover, to establish the strength of the causal relationships we have also used generalized impulse response function (Lutkepohl \& Reimers, 1992; Pesaran \& Shin, 1998; Awokuse, 2008).

\section{Results and Discussion}

The empirical results are reported in this section. Table 1 report the descriptive statistics of the variables. Over the 1995-2018 period, GDP growth, GDP per capita, domestic credit to private sector by banks and stock market liquidity (turnover ratio of domestic shares) averaged 4.87 percent, US $\$ 1,794.70,37.42$ percent and 21.07 percent, respectively.
Table 1: Descriptive Statistics

\begin{tabular}{|l|c|c|c|c|}
\hline \multirow{2}{*}{ Statistics } & \multicolumn{4}{|c|}{ Variables } \\
\cline { 2 - 5 } & GDPGRW & GDPCAP & CREDIT & STOCKS \\
\hline Mean & 4.87 & 1794.70 & 37.42 & 21.07 \\
Median & 5.06 & 1532.23 & 36.32 & 16.11 \\
Maximum & 7.63 & 3102.71 & 56.46 & 64.89 \\
Minimum & -0.58 & 957.28 & 28.69 & 10.55 \\
Std. Dev. & 1.92 & 803.89 & 7.77 & 12.73 \\
Skewness & -1.05 & 0.42 & 0.77 & 2.05 \\
Kurtosis & 4.11 & 1.52 & 2.75 & 7.18 \\
Jarque-Bera & 5.65 & 2.90 & 2.45 & 34.33 \\
Probability & 0.06 & 0.24 & 0.29 & 0.00 \\
Sum & 116.87 & 43072.83 & 898.13 & 505.67 \\
Sum Sq. Dev. & 85.07 & 14863646.00 & 1387.96 & 3729.17 \\
Observations & 24 & 24 & 24 & 24 \\
\hline
\end{tabular}

In Figure 1, the plots of the variables were presented. They did not appear to be integrated of $\mathrm{I}(0)$ or $\mathrm{I}(1)$. To validate the order of integration, this study used ADF and PP tests.

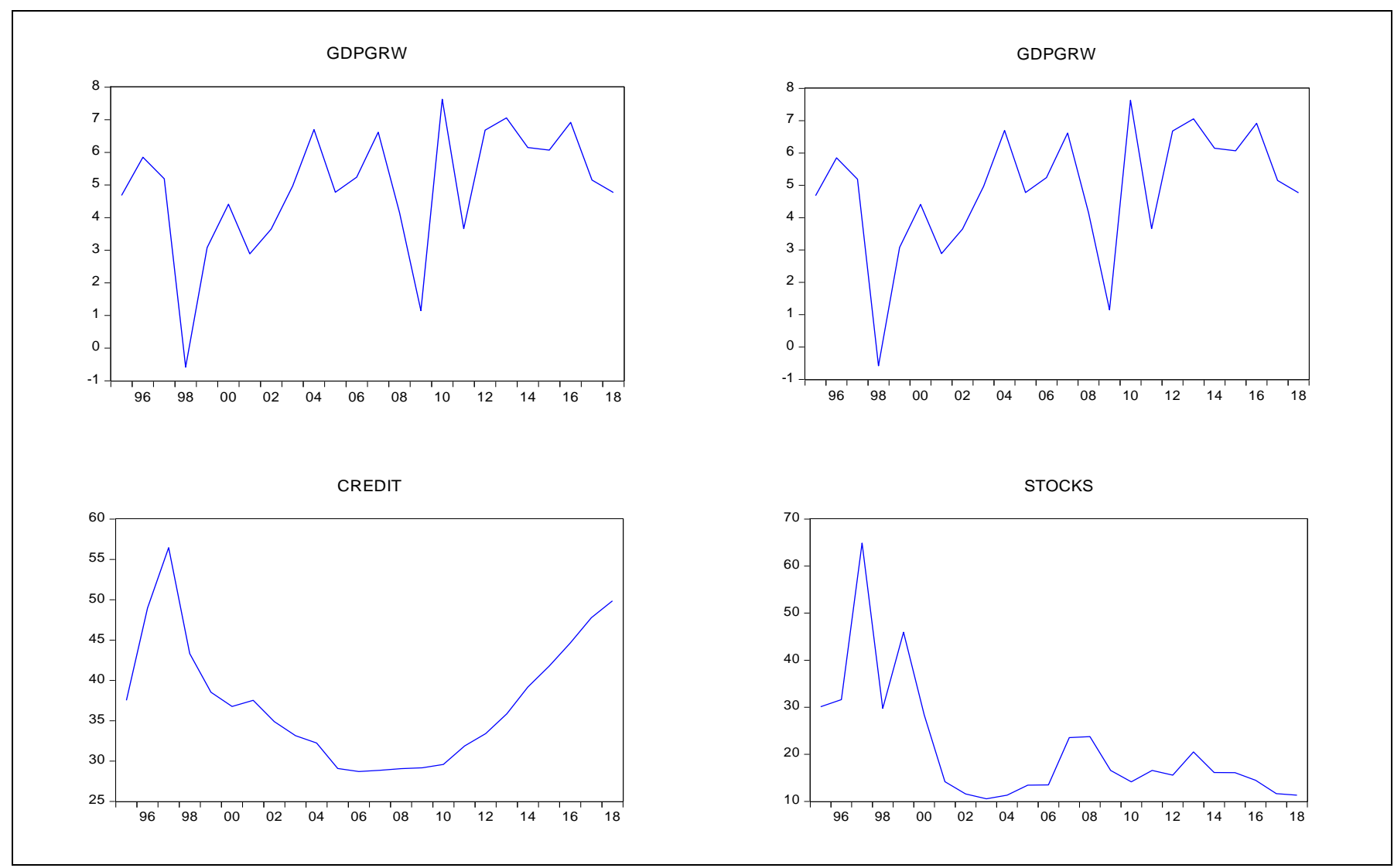

Figure 1: Plots of Variables

\subsection{Augmented Dickey-Fuller and Phillips- Perron Unit Root Tests Results}

Table 2 presented the unit root tests results. The tests results reflect that times series variables, GDP growth (GDPGRW), GDP per capita (GDPCAP), domestic credit (CREDIT) and stock market liquidity (STOCKS) have unit roots in their levels. This is due to the fact that the estimated ADF and PP statistics cannot reject the null hypothesis of non-stationarity at a 5 percent level of significance. However, after first differencing all variables are stationary at 5 percent and 1 percent levels. Hence, the variables are integrated in the first order, I(1). 
Table 2: Results of Unit Root Tests

\begin{tabular}{|c|c|c|c|c|c|}
\hline \multirow{3}{*}{ Variables } & \multicolumn{4}{|c|}{ Test Method } & \multirow{3}{*}{ Inference } \\
\hline & \multicolumn{2}{|c|}{ ADF Test } & \multicolumn{2}{|c|}{ PP Test } & \\
\hline & Level & First Difference & Level & First Difference & \\
\hline GDPCAP & 3.58 & $-3.75^{\star *}$ & 2.98 & $-3.75^{\star \star}$ & Stationary and I(1) \\
\hline CREDIT & 2.03 & $-4.96^{\star *}$ & 0.30 & $-15.52^{\star \star \star}$ & Stationary and I(1) \\
\hline STOCKS & -1.19 & $-7.68^{\star \star \star}$ & -1.31 & $-7.69^{\star \star \star}$ & Stationary and I(1) \\
\hline
\end{tabular}

${ }^{* \star *}$ Indicates statistical significance at a 0.01 level.

**In Indicates statistical significance at a 0.05 level.

$\mathrm{I}(1)$ : intergrated of order one; I(0): intergrated of order zero.

\subsection{Autoregressive Distributed Lag (ARDL) Model and Johansen Cointegration Results}

The above result also points towards the possibility of cointegration. The ARDL model was utilized to establish the cointegration as shown in Table 3. When GDP growth is the dependent variable, the F-statistic of 10.03 was higher than the critical upper bound of 5.00 at 1 percent significance level, which indicated a long-run relationship of domestic credit and stock market liquidity on GDP growth of the Philippines from 1995 to 2018 . When the GDP per capita is the dependent variable there is weak cointegration as defected by the calculated F-statistic equals 3.38, which is greater than the upper critical bound of 3.35 at 10 percent significance level.
Table 3: Results of ARDL Cointegration Test

\begin{tabular}{|c|c|c|c|}
\hline \multicolumn{3}{|c|}{ Model } & F-statistics \\
\hline \multicolumn{3}{|c|}{ Model 1: GDPGRW, CREDIT, STOCKS } & 10.03 \\
\hline \multicolumn{3}{|c|}{ Model 2: GDPCAP, CREDIT, STOCKS } & 3.38 \\
\hline \multirow{4}{*}{$\begin{array}{l}\text { Critical Bounds } \\
\text { F-statistics }\end{array}$} & $\begin{array}{c}\text { Significance } \\
\text { Level }\end{array}$ & $\mathrm{I}(0)$ & $\mathrm{I}(1)$ \\
\hline & $10 \%$ & 2.63 & 3.35 \\
\hline & $5 \%$ & 3.10 & 3.87 \\
\hline & $1 \%$ & 4.13 & 5.00 \\
\hline
\end{tabular}

We also verified the long-run relationship through the cointegration test of Johansen (1988). Both the trace test and max-eigen test indicates 3 cointegrating equations at 0.05 level of significance. Therefore, the results confirmed the existence of long-run relationship of domestic credit and stock market liquidity on GDP growth and GDP per capita, from 1995 to 2018 in the Philippines. The results are made available in Table 4.

Table 4: Results of Johansen Cointegration Test

\begin{tabular}{|c|c|c|c|c|c|c|}
\hline $\begin{array}{l}\text { Hypothesized } \\
\text { Number of } \\
\text { Cointegrating } \\
\text { Equations }\end{array}$ & \multicolumn{2}{|c|}{$\begin{array}{l}\text { Model 1: GDPGRW, CREDIT, } \\
\text { STOCKS }\end{array}$} & \multicolumn{2}{|c|}{$\begin{array}{l}\text { Model 2: GDPCAP, CREDIT, } \\
\text { STOCKS }\end{array}$} & \multicolumn{2}{|c|}{$\begin{array}{c}\text { Critical Value } \\
(0.05 \text { level })\end{array}$} \\
\hline None $^{* \star}$ & 62.17 & 33.72 & 54.48 & 34.72 & 29.80 & 21.13 \\
\hline At most $1^{* *}$ & 28.44 & 15.36 & 19.76 & 14.88 & 15.49 & 14.26 \\
\hline At most $2^{* *}$ & 13.09 & 13.09 & 4.87 & 4.87 & 3.84 & 3.83 \\
\hline
\end{tabular}

${ }^{* *}$ denotes rejection of the hypothesis at the 0.05 level.

The normalized cointegrating equations for GDP growth and GDP per capita were given in Table 5. The equations show that in the long-run stock market liquidity affect GDP growth negatively and significantly at 5 percent level. This negative but significant effect of stock market liquidity can be attributed to the stock market liquidity creating ability, that is, liquidity can in fact deter economic growth (Demirguc-Kunt \& Levine, 1996) or possibly depress business investment and economic activity (Bhattacharya, Bhattacharya, \& Basu, 2019). The cointegrating equation further indicated that in the long-run domestic credit ( 0.05 level) and stock market liquidity (0.01 level) have positive and significant effect on GDP per capita. The coefficient of domestic credit (-10.63) is positive and significant, implying that banks efforts of resource mobilization affect economic growth in the long-run. Moreover, the coefficient of stock market liquidity (-25.79) is also positive and significant, implies that stock market development is conducive to longrun economic growth. A well-organized and active stock market would help create liquidity that eventually enhances economic growth for the Philippines.

\begin{tabular}{|c|c|c|}
\hline D(GDPGRW) & D(CREDIT) & D(STOCKS) \\
\hline 1.00 & $\begin{array}{l}0.06 \\
(0.07)\end{array}$ & $\begin{array}{l}0.073 \\
(0.04)^{\star *}\end{array}$ \\
\hline D(GDPCAP) & D(CREDIT) & D(STOCKS) \\
\hline 1.00 & $\begin{array}{l}-10.63 \\
(5.88)^{\star *}\end{array}$ & $\begin{array}{l}-25.79 \\
(3.06)^{\star \star *}\end{array}$ \\
\hline
\end{tabular}

${ }^{* \star *}$ indicates significance at the 0.01 level.

**indicates significance at the 0.05 level. 


\subsection{Granger Causality Based on Vector Error Correction Model (VECM) Results}

Table 6 reports the results of the VECM estimates. The coefficient of ECM is -1.43 (correct) and its t-statistic is 6.74 with p-value $=0.00$ which is significant 0.01 level. A negative and significant coefficient of the ECM implies long-run causality running from domestic credit and stock market liquidity to GDP growth. The speed of adjustment is 1.43 , means that the whole system is going back to long-run equilibrium at the speed 143 percent annually. At levels, domestic credit has significant short-run causal relationship with GDP growth (0.05 level). As for stock market liquidity at first lag, has significant short-run causal relationship with GDP growth (0.05 level). Therefore, in the short-run, increases in domestic credit and stock market liquidity Granger cause GDP growth.

For the long-run causality between GDP per capita, domestic credit and stock market liquidity the results of the VECM estimates indicate that the coefficient of the error correction term of 0.06 is positive (incorrect), however, significant at 1 percent level. Thus, the results indicated lack of significant adjustments towards long-run equilibrium in any disequilibrium situation. Further, at levels the coefficient of stock market liquidity was 5.04 and significant. Thus, the results indicate the presence of short-run causality from stock market liquidity to GDP per capita.
Table 6: Results of ARDL Error Correction Regression Dependent Variable: GDPGRW

\begin{tabular}{|l|l|l|l|}
\hline \multicolumn{1}{|c}{ Coefficient } & \multicolumn{1}{l|}{ t-statistic } & \multicolumn{1}{l|}{ Prob. } \\
\hline Constant & 8.81 & 6.51 & $0.00^{\star * \star}$ \\
\hline D(CREDIT) & 0.24 & 2.36 & $0.03^{\star \star}$ \\
\hline D(STOCKS) & 0.02 & 0.56 & 0.58 \\
\hline D(STOCKS $(-1))$ & 0.08 & 2.27 & $0.03^{\star \star}$ \\
\hline ECM & -1.43 & -6.74 & $0.00^{\star \star *}$ \\
\hline
\end{tabular}

R-squared $=0.80 \quad$ Adjusted R-squared $=0.75 \quad \mathrm{DW}=1.94$

F-statistic $=16.65$ Probability (F-statistics $)=0.00$

Dependent Variable: GDPCAP

\begin{tabular}{|c|c|c|c|}
\hline & Coefficient & t-statistic & Prob. \\
\hline Constant & 351.88 & 5.40 & $0.00^{\star \star \star}$ \\
\hline D(STOCKS) & 5.04 & 3.30 & $0.00^{\star \star \star}$ \\
\hline ECM & 0.06 & 4.15 & $0.00^{\star * \star}$ \\
\hline
\end{tabular}

R-squared $=0.55 \quad$ Adjusted R-squared $=0.51 \quad \mathrm{DW}=2.36$

F-statistic $=12.42$ Probability (F-statistics $)=0.00$

***indicates significance at the 0.01 level.

**indicates significance at the 0.05 level.

The stability of the estimated GDP growth model and GDP per capita model were tested using cumulative sum of recursive residuals (CUSUM) and cumulative sum of squares of recursive residuals (CUSUMSQ). Figure 2 suggest that the null hypothesis of stable coefficients cannot be rejected at the 5 percent level of significance for both CUSUM and CUSUMSQ tests as the cumulated sum stays within the 95 percent confidence band. Supporting model stability, the CUSUM plot implies that the models are not misspecified and CUSUMSQ plot complements the findings of the CUSUM plot to suggest no structural change in the models over time. Thus, the estimated models for GDP growth and GDP per capita were stable during the 19952018 period.

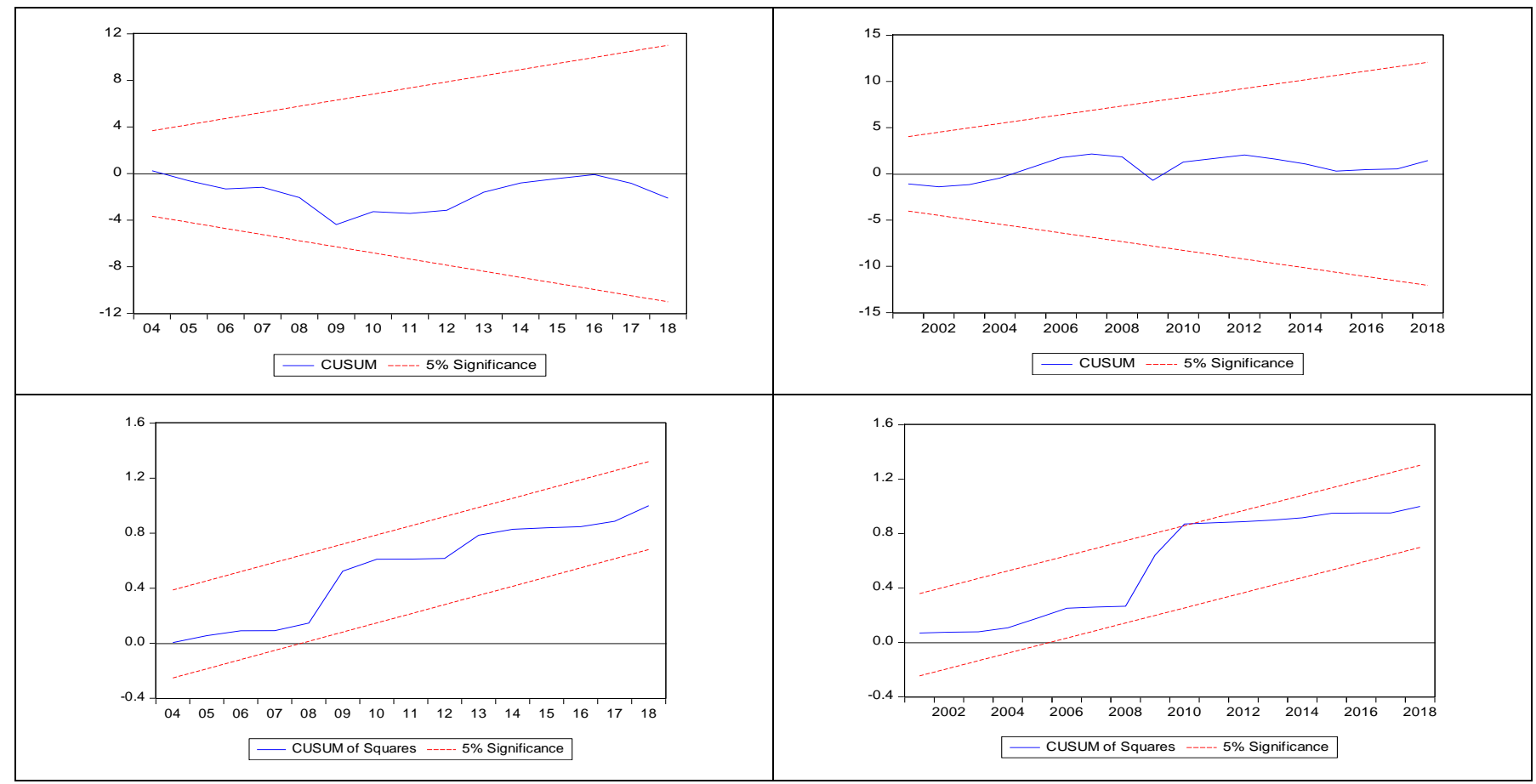

Figure 2: CUSUM and CUSUMSQ Plots for Stability Tests 
The use of the generalized impulse response functions showed the short-run and long-run shock to GDP growth were insignificant. As for GDP per capita, the short-run and long-run innovation or shock remained high. The shocks of domestic credit and stocks market liquidity differs and remain low in the short-run and in the long-run to influence the fluctuations of the dependent variables or impulse receivers (GDP growth and GDP per capita). Figure 3 display the results of the generalized impulse response functions.

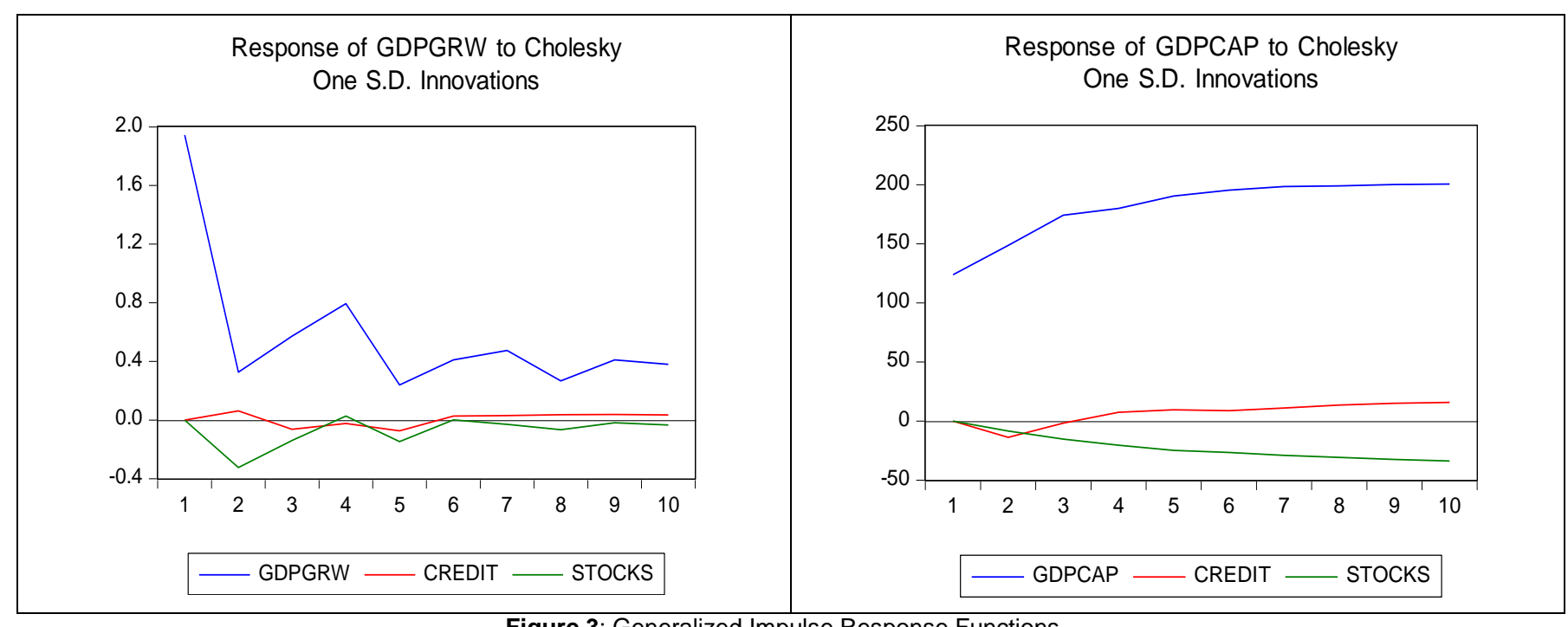

Figure 3: Generalized Impulse Response Functions

\section{Conclusions}

The paper examined the dynamic relationship of domestic credit and stock market liquidity on the economic growth of the Philippines from 1995 to 2018 applying the autoregressive distributed lag (ARDL) bounds testing approach to cointegration, together with Granger causality test based on vector error correction model (VECM). Using the ARDL model and cointegration test of Johansen (1988) this study reached the conclusion that domestic credit and stock market liquidity have long-run equilibrium relationship with economic growth (i.e., GDP growth and GDP per capita). Likewise, the vector error correction model (VECM) concludes short-run and long-run causality running from domestic credit and stock market liquidity to economic growth (i.e., GDP growth and GDP per capita).

The paper validated the beliefs that financial market development (i.e., banking sector development and stock market development) significantly affect economic growth. A policy implication of the above conclusions is that domestic credit and stock market liquidity can be considered as key policy variables to generate economic growth for the Philippines in the short- and long-run periods. Although the Philippine stock market has improved substantially over the period 1995-2018, it still faces a wide range of challenges (i.e., less diversified investor base, lack of competition from regional counterparts, and a weak legal framework for financial market development). Likewise, a flexible banking system encourages easier access to funds by small and medium enterprises (SMEs) is essential to increasing economic growth. In particular, policymakers need to focus more on making credits from banks more accessible and may look at the stock market liquidity issue more seriously. Such policy could be supported by continuously promoting a well-developed financial infrastructure in order to establish depth in financial services for the Philippine economy.

\section{References}

Acharya, P. (2015). The Variance decomposition of GDP, domestic credit and exports of Nepal: A VAR approach. NRB Working Paper, 28, 1-16.

Arestis, P., Demetriades, P., \& Luintel, K. (2001). Financial development and economic growth: The role of stock markets. Journal of Money, Credit and Banking, 33(1), 16-41.

Awokuse, T. O. (2008). Trade openness and economic growth: Is growth export-led or import-led? Applied Economics, 40(1), 161-173.

Bhattacharya, S., Bhattacharya, M., \& Basu, S. (2019). Stock market and its liquidity: Evidence from ARDL bound testing approach in the Indian context. Cogent Economics \& Finance, 7(1), 1-12.

Bayar, Y. (2014). Financial development and economic growth in emerging Asian countries. Asian Social Science, 10(9), 8-17.

Beck, T., \& Levine, R. (2003). Stock markets, banks, and growth: Panel evidence. Journal of Banking and Finance, 28(3), 423-442.

Beck, T., Levine R., \& Loayza, N. (2000). Finance and sources of growth. Journal of Financial Economics, 58(1- 2), 261-300.

Bhusal, B. P. (2012). The Impact of financial policy reforms 
on financial development and economic growth in Nepal. International Journal of Business and Social Science, 3(14), 33-45.

Burnham, K. P., \& Anderson, D. R. (2004). Multimodal inference: Understanding AIC and BIC in model selection. Sociological Methods and Research, 33(1), 261-304.

Caporale, G., Howells, P., \& Soliman, M. (2004). Stock market development and economic growth: The causal linkage. Journal of Economic Development, 29(1), 33-50.

Demirguc-Kunt, A. (1994). Developing country capital structure and emerging stock markets. Policy Research Working Paper, WPS 933.

Demirguc-Kunt, A., \& Levine, R. (1996). Stock markets, corporate finance and economic growth: An overview. World Bank Economic Review, 10, 223-239.

Dickey, D. A., \& Fuller, W. A. (1981). Likelihood ratio statistics for autoregressive time series with a unit root. Econometrica, 49(1), 1057-1072.

Ho, S., \& Odhiambo, N. (2015). Stock market development in the Philippines: Past and present. Philippine Journal of Development Volumes, 42(2), 135-156.

Johansen, S. (1988). Statistical analysis of cointegration vectors. Journal of Economic Dynamics and Control, 12(2-3), 231-254.

Khanal, D. R. (2007). Banking and insurance services liberalization and development in Bangladesh, Nepal and Malaysia: A comparative analysis. Asia-Pacific Research and Training Network on Trade Working Paper Series, No. 4.

Kharel, R., \& Pokhrel, D. (2012). Does Nepal's financial structure matter for economic growth? NRB Working Paper, Serial No. NRB/WP/10, July 2012.

Krishnankutty, R. (2011). Role of banks credit in economic growth: A study with special reference to North East India. The Economic Research Guardian, 1(2), 60-71.

Levine, R., \& Zervos, S. J. (1995). Stock market development and long-run growth. World Bank Economic Review, 82(4), 942-963.

Lutkepohl, H., \& Reimers, H. E. (1992). Impulse response analysis of cointegrated systems. Journal of Economic Dynamics and Control, 16(1), 53-78.
Narayan, P. K., \& Smyth, Y. (2005). Trade liberalization and economic growth in Fiji: An empirical assessment using ARDL approach. Journal of the Asia Pacific Economy, 10(1), 96-115.

Nazir, M., Nawaz, M., \& Gilani, U. (2010). Relationship between economic growth and stock market development. African Journal of Business Management, 4(16), 3473-3479.

Patra, S., \& Dastidar, S. G. (2018). Finance and growth: Evidence from South Asia. Jindal Journal of Business Research, 7(1) 37-60.

Paudel, N. P. (2005). Financial system and economic development. Nepal Rastra Bank in fifty years, Part -II. Financial System. Kathmandu: NRB.

Pesaran, H. H., \& Shin, Y. (1998). Generalized impulse response analysis in linear multivariate models. Economics Letters, 58(1), 17-29.

Pesaran, M., \& Shin, Y. (1999). An autoregressive distributive lag modelling approach to cointegration analysis. Econometrics and economic theory in $20^{\text {th }}$ century: the Ragnar Frisch centennial symposium. Cambridge, UK: Cambridge University Press, 371-413.

Pesaran, M. H., Shin, Y., \& Smith, R. J. (2001). Bounds testing approaches to the analysis of level relationships. Journal of Applied Econometrics, 16(3), 289-326.

Phillips, P. C., \& Perron, P. (1988). Testing for a unit root in time series regression. Biometrica, 75(1), 335-346.

Rana, R., \& Barua, S. (2015). Financial development and economic growth: Evidence from a panel study on South Asian Countries. Asian Economic and Financial Review, 5(10), 1159-1173.

Rousseau, P. L., \& Wachtel, P. (2000). Equity markets and growth: Cross-country evidence on timing and outcomes, 1980-1995. Journal of Banking and Finance, 24(12), 1933-1957.

Rudra, P., Nishigaki, Y., \& Hall, H. (2017). The multivariate dynamic causal relations between financial depth, inflation, and economic growth. The Philippine Review of Economics, 54(1), 63-93.

Vaithilingam, S., Guru, B. K., \& Shanmugam, B. (2003). Bank lending and economic growth in Malaysia. Journal of Asia-Pacific Business, 5(1), 51-69. 